\title{
Feeding activity of the cayenne pompano Trachinotus cayennensis (Cuvier 1832) (Perciformes, Carangidae) in estuaries on the western coast of the state of Maranhão, Brazil
}

\author{
A. C. L. Castro ${ }^{a, b *}$, J. W. J. Azevedo ${ }^{a, c}$, H. R. S. Ferreira ${ }^{\text {, L L. S. Soares }}{ }^{a}$, J. R. Pinheiro-Júnior ${ }^{a}$, \\ L. M. R. Smith ${ }^{a}$ and M. H. L. Silva ${ }^{a, c}$ \\ ${ }^{a}$ Departamento de Oceanografia e Limnologia, Universidade Federal do Maranhão - UFMA, \\ Av. dos Portugueses, 1966, CEP 65080-805, São Luís, MA, Brasil \\ 'Programa de Pós-graduação em Saúde e Ambiente, Universidade Federal do Maranhão - UFMA, \\ Av. dos Portugueses, 1966, CEP 65080-805, São Luís, MA, Brasil \\ 'Programa de Pós-graduação em Biodiversidade e Biotecnologia, Rede BIONORTE, Universidade Federal do Maranhão - \\ UFMA, Av. dos Portugueses, 1966, CEP 65080-805, São Luís, MA, Brasil \\ dPrograma de Pós-graduação em Oceanografia, Universidade Federal do Maranhão - UFMA, \\ Av. dos Portugueses, 1966, CEP 65080-805, São Luís, MA, Brasil \\ *e-mail: alec@ufma.br
}

Received: July 13, 2017 - Accepted: 7 Nov. 2017 - Distributed: May 31, 2019

(With 6 figures)

\begin{abstract}
The present paper addresses the feeding activity of Trachinotus cayennensis, collected in Lençóis Bay $\left(1^{\circ} 18^{\prime} \mathrm{S}-1^{\circ} 19^{\prime} \mathrm{S}\right.$; $\left.44^{\circ} 51^{\prime} \mathrm{W}-44^{\circ} 53^{\prime} \mathrm{W}\right)$ on the western coast of the state of Maranhão, Brazil. Sampling was conducted between June 2012 and June 2013 using driftnets with stretch mesh sizes from 95 to $100 \mathrm{~mm}$. A total of 205 individuals (114 females and 91 males) were analyzed. Statistically significant differences in the sex ratio were found in June, September and December 2012. Food items were analyzed based on frequency of occurrence and volumetric method, with the subsequent calculation of the alimentary importance index. Three size groups were defined to determine possible ontogenetic changes in eating habits based on the size range of the individuals collected: I $(<29 \mathrm{~cm})$, II (29.1 to 37.0) and III ( $\geq 37.1)$. Eleven food item categories were identified: mollusks, polychaetes, crustaceans, nematodes, insects, algae, bryozoans, ophiuroids, fishes, vegetal matter and sediments. The variety of items in the diet of $T$. cayennensis indicates considerable feeding plasticity and opportunistic behavior. Seasonal variations influenced the feeding pattern of the species, with greater feeding activity in the dry season. The considerable availability of resources in estuarine habitats of the western coast of Maranhão constitutes another factor that influences the feeding behavior of this species.
\end{abstract}

Keywords: diet composition, food items, stomach, trophic pattern.

\section{Atividade alimentar do pampo Trachinotus cayennensis (Cuvier 1832) (Perciformes, Carangidae) em estuários do litoral ocidental do Estado do Maranhão, Brasil}

\section{Resumo}

Atividade alimentar do pampo Trachinotus cayennensis (Cuvier 1832) (Perciformes, Carangidae) em estuários na costa ocidental do Maranhão, Brasil. O presente trabalho descreve a atividade alimentar do Trachinotus cayennensis, coletado na Baía de Lençóis $\left(1^{\circ} 18^{\prime} \mathrm{S}-1^{\circ} 19^{\prime} \mathrm{S} ; 44^{\circ} 51^{\prime} \mathrm{W}-44^{\circ} 53^{\prime} \mathrm{W}\right)$ na costa oeste do Maranhão. Amostragens foram realizadas entre junho de 2012 e junho de 2013, utilizando redes de emalhar à deriva com tamanho de malha de 95 a $100 \mathrm{~mm}$. Foram analisados 205 indivíduos (114 fêmeas e 91 machos). Encontraram-se diferenças estatisticamente significativas na proporção sexual nos meses de junho, setembro e dezembro de 2012. Os itens alimentares foram analisados com base na frequência de ocorrência e utilizando o método volumétrico, com o subsequente cálculo do índice de importância alimentar. Três grupos de tamanho foram definidos para determinar possíveis mudanças ontogenéticas nos hábitos alimentares com base na faixa de tamanho dos indivíduos coletados: I ( $<29 \mathrm{~cm})$, II $(29,1$ a 37,0$)$ e III $(\geq 37,1)$. Foram identificadas 11 categorias de alimentos: moluscos, poliquetas, crustáceos, nematoides, insetos, algas, briozoários, ophiuro, peixes, matéria vegetal e sedimentos. A variedade de itens na dieta de T. cayennensis indica uma plasticidade alimentar considerável e um comportamento oportunista. As variações sazonais influenciaram o padrão alimentar da espécie, com maior atividade de alimentação na estação seca. A considerável disponibilidade de recursos nos habitats estuarinos da costa oeste do Maranhão constitui outro fator que exerce influência sobre o comportamento alimentar desta espécie.

Palavras-chave: composição da dieta, itens alimentares, estômago, padrão trófico. 


\section{Introduction}

Studies of the feeding ecology of a species provides basic biological knowledge and may allow inferences regarding its population dynamics, contributing to the understanding of such subjects as resource partitioning, habitat preferences, prey selection, predation, evolution, competition and energy transfer within and between ecosystems (Wootton, 1992; Lima and Behr, 2010). Thus, studies based on the analysis of stomach contents are among of the few resources that can provide information on feeding ecology and the trophic spectrum of fishes in their natural habitat (Palmeira and Monteiro-Neto, 2010).

Quantitative information about the diet of aquatic organisms is essential to the development of models that consider trophic interactions and nutrient flow in aquatic systems and is one of the basic requirements for a closer examination of the relationships between fishes and their habitats (Fatema et al., 2013; Campos et al., 2015).

In tropical regions, although there are fishes that consume specific types of food, most species exhibit great plasticity in their diets (Lowe Mcconnell, 1999), making it difficult to verify patterns well defined. This food plasticity is an interaction between the quality/quantity of the food available in the environment and the degree of morphological and behavioral restrictions exhibited by the species and that are associated with ontogenetic variations (Luz et al., 2001).

Species of the genus Trachinotus have been studied worldwide with regard to their viability for aquiculture due to characteristics such as rapid adaptation to captivity, good tolerance to extreme environmental conditions, high resistance to pathogens and rapid growth (Gómes, 2002). However, information related to its trophic ecology is available only to the coastal regions of the southeastern Brazil.

The Trachinotus cayennensis (Cuvier, 1832), which occurs from Venezuela to the state of Paraíba in northeastern Brazil, is among the fishing resources of great abundance in tropical regions. However, there is no scientific information about its population dynamics in the western coast of Maranhão. Although Lençois Bay is located in the largest protected coastal area in the state, there is a lack of studies about the behavior of migrant marine fish species that use the estuarine environment as a feeding area. The feeding behavior of Trachinotus cayennensis has been described by different authors as a fish with foraging habits in the bottom, which indicates a diet consisting predominantly of benthic invertebrates, crustaceans, mollusks and, to a lesser extent, fishes being considered exclusively benthic feeders (Menezes and Figueiredo, 1980; Bellinger and Avault-Júnior, 2011; McMaster, 2014).

Studies about variations between size classes by sex associated with food supply of marine fish species have been carried out around the world to increase the knowledge of the trophic dynamics and food strategy of species and the complete understanding of their functional role within an ecosystem (Oliveira et al., 2012; Fontelles-Filho, 2011).
The aim of the present was to investigate the feeding spectrum of Trachinotus cayennensis in the estuarine system of Lençois Bay in the state of Maranhão (eastern Amazon) assuming that the food strategy of the species is associated with estuarine dynamics and the supply of items available in the environment.

\section{Materials and Methods}

\subsection{Study site}

The state of Maranhão has the second largest coast of Brazil, with 640 kilometers of coast, and the largest hydrographic basin in the Northeast, generating a combination of large tides and large perennial rivers. The Maranhão western coast includes the area between the mouth of the Gurupi River and the Maranhense Gulf, forming a system called Reentrâncias Maranhenses, characterized by the conformation of a fairly trimmed coastline, consisting of an expressive set of islands, peninsulas and bays, cut by rivers streams and tidal channels filled with clay and silt which foster the development of mangroves (El-Robrini et al., 2006; Rebelo-Mochel and Ponzoni, 2007). In addition, the high concentration of nutrients and other favorable environmental conditions, such as thermal gradients and variable salinity, and the exceptional conditions of shelter and reproduction support and the initial feeding of some marine and estuarine species, make this region one of the main focuses of attention in relation to environmental conservation and the maintenance of its biodiversity (Lefèvre et al., 2017).

This study was conducted in estuarine areas of Lençóis Bay $\left(1^{\circ} 18^{\prime} \mathrm{S}-1^{\circ} 19^{\prime} \mathrm{S} ; 44^{\circ} 51^{\prime} \mathrm{W}-44^{\circ} 53^{\prime} \mathrm{W}\right)$ (Figure 1). Lençóis Island is located in the Maiau archipelago on the coast of the city of Cururupu, state of Maranhão, eastern Amazon, which is an eco-tourism center in the Guarás Forest.

Reschke et al. (2011), agreeing to the climatic classification described by Thornwaite in the year 1948, defines the climate of the Lençóis Bay as wet type B2. It is the transition between the super humid of the Amazon and the semiarid of the Northeast. The annual average temperature ranges from $25^{\circ} \mathrm{C}$ to $27^{\circ} \mathrm{C}$ and the annual average rainfall reaches $2.500 \mathrm{~mm}$. The rainy period takes place from January to June and the dry period extends from July to December.

The landscape consists of mangrove vegetation composed of Rhizophora mangle, Avicennia germinans and Laguncularia racemosa. The tallest mangroves trees are concentrated in the northeastern and southeastern sectors of Lençóis Island, with trees of the $R$. mangle species reaching 25 meters and dominating the local landscape.

\subsection{Data collection}

Samples were taken bimonthly between June 2012 and June 2013 to include the environmental and climatic variability of the region. In order to do that, floating drift gillnets with a mesh size of $100 \mathrm{~mm}$ between adjacent knots, 40 meshes in height and 2500 meters in length were used. All catches were performed in the evening from 


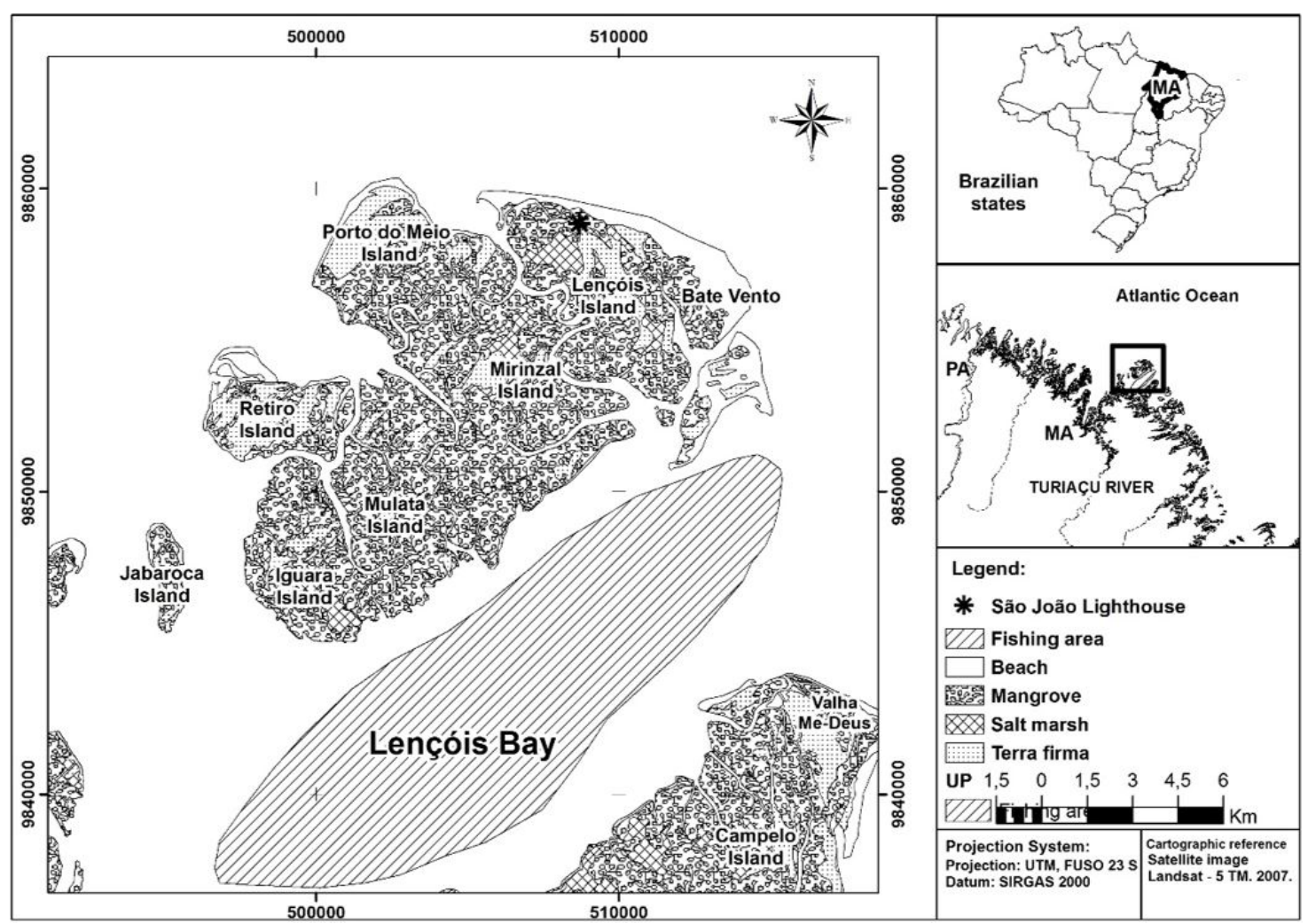

Figure 1. Location of Lençóis Bay and catch area identified by hatched line.

18:00 to 24:00 $\mathrm{h}$, operating in an area of approximately $110 \mathrm{Km}^{2}$ at depths of 10 to 15 meters. Captured individuals under the ICMBio license number 60866 were euthanized on ice and taken to the laboratory. After the sampling procedures, the samples were immediately fixed in formalin $10 \%$. Voucher material was deposited at the Ichthyology Collection of the Department of Oceanography and Limnology of the Federal University of Maranhão, Brazil (CPUFMA 122823 to 132828) and were approved by the Ethics Committee of Maranhão Federal University under number 735.760.

In the laboratory, specimens were identified based on Figueiredo and Menezes (2000). Basic morphological measurements were taken for each specimen, including total length $(\mathrm{cm})$ and body weight $(\mathrm{g})$. The specimens were then dissected through a longitudinal incision in the ventral region to remove the entire digestive tract. The stomach of each individual was weighed both full and empty. The volume $(\mathrm{mL})$ of each item was obtained from the displacement of liquid in a millimeter beaker (Hyslop, 1980; Capitoli, 1992).

The determination of the feeding activity period was performed by identifying the degree of stomach fullness of the specimens through a visual examination. The stomachs were classified as empty, partially empty, partially full and full (Hyslop, 1980; Zahorcsak et al., 2000). Food items in an advanced state of digestion were classified as digested organic matter.

\subsection{Data analysis}

The definition of class intervals followed a recommendation in which the width of length groups for a length frequency histogram generally depends on maximum and minimum fish lengths and the number of individuals measured (Zale et al., 2012). The sex ratio was determined for males and females (M:F) throughout the sampling period. The chi-squared $\left(\chi^{2}\right)$ with a significance level of $\alpha=0.05$ was used to determine significant differences in the sex ratio from the commonly expected 1:1 ratio.

Food items were analyzed based on frequency of occurrence and using the volumetric method (Hynes, 1950), with the subsequent calculation of the alimentary importance index (IAi) adopted from Kawakami and Vazzoler (1980). The expressions that define each method used are as follows $(1,2,3)$ :

- Frequency of occurrence $\left(\% \mathrm{~F}_{\mathrm{oc}}\right)$ (Hyslop, 1980) $\rightarrow$ calculated by the percentage of stomachs with a particular item in relation to the total number of stomachs analyzed with food.

$\% F_{o c}=\frac{F_{i}}{F_{t}} x 100$

$\mathrm{F}_{\mathrm{i}}$ : number of stomachs in which item i occurred

$F_{t}$ : total number of stomachs with food 
- Volumetric frequency (Vl):

$\% \boldsymbol{V}=\frac{V_{i} * 100}{\boldsymbol{V}}$

$V i=$ volumetric frequency of item $i$ in diet of species;

$V=$ volume of food item i;

- Alimentary Importance Index (IAi):

$\% \mathbf{I A i}=\frac{F_{i} * V_{i}}{\sum_{i=1}^{n}\left(F_{i} * V_{i}\right)} x 100$

$\mathrm{IAi}=$ alimentary importance index (between 0 and 100);

$\mathrm{Fi}=$ frequency of occurrence of food item $\mathrm{i}$;

$\mathrm{Vi}=$ volume of food item $\mathrm{i}$;

$\mathrm{i}=$ food item

Three size groups were defined to determine possible ontogenetic changes in eating habits within the size range of the individuals collected: I $(<29 \mathrm{~cm})$, II (29.1 to 37.0) and III $(\geq 37.1)$. In order to observe possible associations of size groups to food items, a Principal Component Analysis (PCA) was performed from a variance-covariance matrix of the IAi (\%) data. PCA was processed using the PRIMER $^{\circledR} 6$ statistical program (Clarke and Gorley, 2001), and a square root transformation was performed for all data, prior to multivariate analysis.

Variations in the diet of $T$. cayennensis in the different months were analyzed using nonmetric multidimensional scaling (NMDS) (Clarke and Warwick, 1994). The frequency of occurrence values for each category were transformed into respective square roots for the calculation of a matrix of similarity based on the Bray-Curtis similarity index run in the PRIMER ${ }^{\circledR} 6$ statistical program (Clarke and Gorley, 2001). The choice of the graphical representation in the reduced space was defined from the lower value of the stress coefficient (Valentin, 2012).

After the ordering and formation of the groups of months, a similarity percentage analysis (SIMPER) was computed in order to identify which food items contributed to the formation of the groups. This analysis was done with the objective of identifying the items that are primarily responsible for discrimination between two groups of samples observed in the analysis and to identify the importance of each item within the seasonal group through the product between dissimilarity and standard deviation (Clarke and Gorley, 2001).

\section{Results}

A total of 205 specimens of Trachinotus cayennensis were analyzed: 114 females, 66 males and 25 individuals of unidentified sex. Total length ranged from 19.5 to $49.0 \mathrm{~cm}$ and total biomass was $55,711.64 \mathrm{~g}$.

There was alternation between male and female specimens over the months. Males predominated between September and November 2012, whereas females predominated between December 2012 and June 2013. However, statistically significant differences in the sex ratio only occurred in June, September and December 2012 (Table 1).

The length frequency distribution showed a predominance of females in most classes. The class with the highest number of individuals (males and females) was 29.17 to $33.04 \mathrm{~cm}$. Only females were found in the class between 48.52 and 52.39 (Figure 2).

Eighty-three $(40.49 \%)$ of the stomachs were full, $70(34.15 \%)$ were partially full, $46(22.44 \%)$ were partially empty and only six stomachs (2.93\%) were empty (Table 2).

Among the specimens analyzed, 199 (97.1\%) had stomach contents and six $(2.9 \%)$ had no stomach contents, demonstrating relatively constant feeding activity throughout the period investigated. Eleven categories of food items were identified: mollusks, polychaetes, crustaceans, nematodes, insects, algae, bryozoans, ophiuroids, fishes, vegetal matter

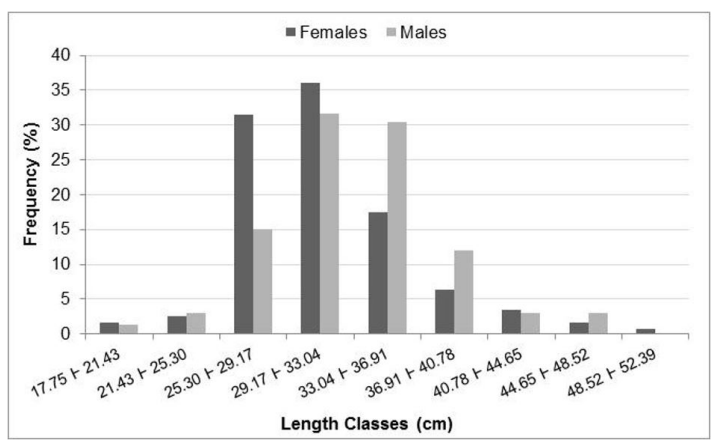

Figure 2. Range of length classes for male and female specimens of Trachinotus cayennensis captured on western coast of Maranhão.

Table 1. Frequency of male and female specimens of T. cayennensis caught from June 2012 to June 2013.

\begin{tabular}{ccccccc}
\hline Month & Males & $\mathbf{\%}$ & Females & $\mathbf{\%}$ & Total & $\boldsymbol{\chi}^{\mathbf{2}}$ \\
\hline Jun/12 & 2 & 15.38 & 11 & 84.62 & 13 & $6.23^{*}$ \\
Sept/12 & 34 & 68.00 & 16 & 32.00 & 50 & $6.48^{*}$ \\
Nov/12 & 8 & 57.14 & 6 & 42.86 & 14 & 0.29 \\
Dec/12 & 20 & 31.25 & 44 & 68.75 & 64 & $9.00^{*}$ \\
Apr/13 & 4 & 28.57 & 10 & 71.43 & 14 & 2.57 \\
May/13 & 7 & 77.78 & 2 & 22.22 & 9 & 2.78 \\
Jun/13 & 16 & 39.02 & 25 & 60.98 & 41 & 1.98 \\
TOTAL & 91 & 44.39 & 114 & 55.61 & 205 & \\
\hline
\end{tabular}

*Statistically significant at 5\% level. 
and sediments. The predominant items included digested organic matter (32\%), shells (28\%), shrimps (9\%), vegetal matter (7\%), algae (6\%) and unidentified material (4\%), followed by ophiuroids, fishes, polychaetes, crabs, worms, insects and bryozoans, which together totaled $9 \%$.

The analysis of diet composition based on frequency of occurrence revealed that $T$. cayennensis ingests food found throughout the water column as well as allochthonous material, such as insects and vegetal matter. Shells and digested organic matter items were frequent and prevalent in all sampling months (Figure 3 ). In the dry period (September, November and December 2012), the species showed greater feeding plasticity, with the presence of quite diverse food items in the stomachs of the specimens analyzed, such as shells, algae, shrimps, crabs, fishes, insects, ophiuroids, nematodes, plants and polychaetes. The reduction in feeding plasticity in the rainy season (April, May and June 2013) may be attributed to low rainfall in this period.

Volumetric analysis of the food items indicated digested organic matter (ranging from 18.1 to $70.8 \%$ ) and shells (14.3 to $72.7 \%)$ as the components with the greatest participation and most significant volumes among the food items (Figure 3). The presence of crustaceans (shrimps and crabs) and mollusks (bivalves) throughout all months sampled confirms findings reported by Menezes and Figueiredo (1980), who described T. cayennensis as a species with predatory habits, feeding on smaller organisms.

The alimentary importance index (IA) confirmed the results of the previous methods, highlighting digested organic matter, shells, crabs and shrimps as the items of greatest importance in the diet of T. cayennensis (Figure 4).

Table 3 displays the proportion of each item found in the diet of $T$. cayennensis distributed by length class. This analysis suggests a change in the food pattern as a function of size, with larger individuals feeding predominantly on shells and crabs.

Components 1 and 2 of Principal Component Analysis (PCA) between size groups and food items explained $100 \%$ of the data variance, $79.7 \%$ of which was related to PC1 and $20.3 \%$ to PC2. A higher degree of similarity was observed between the larger size classes (II and III), associated with foods such as shell, crabs, fishes, shrimps,

Table 2. Fullness of stomachs of T. cayennensis specimens captured on western coast of Maranhão.

\begin{tabular}{cccccccccc}
\hline MONTHS & Empty & $\mathbf{\%}$ & P. Empty & $\mathbf{\%}$ & P. Full & $\mathbf{\%}$ & Full & $\mathbf{\%}$ & Total \\
\hline Jun/12 & & & 1 & 7.7 & 3 & 23.1 & 9 & 69.2 & 13 \\
Sept/12 & 3 & 6.0 & 11 & 22.0 & 14 & 28.0 & 22 & 44.0 & 50 \\
Nov/12 & & & 8 & 57.1 & 5 & 35.7 & 1 & 7.1 & 14 \\
Dec/12 & 2 & 3.1 & 7 & 10.9 & 20 & 31.2 & 35 & 54.7 & 64 \\
Apr/13 & 1 & 7.1 & 9 & 64.3 & 3 & 21.4 & 1 & 7.1 & 14 \\
May/13 & & & 1 & 11.1 & 6 & 66.7 & 2 & 22.2 & 9 \\
Jun/13 & & & 9 & 21.9 & 19 & 46.3 & 13 & 31.7 & 41 \\
TOTAL & 6 & & 46 & & 70 & & 83 & & 205 \\
\hline
\end{tabular}

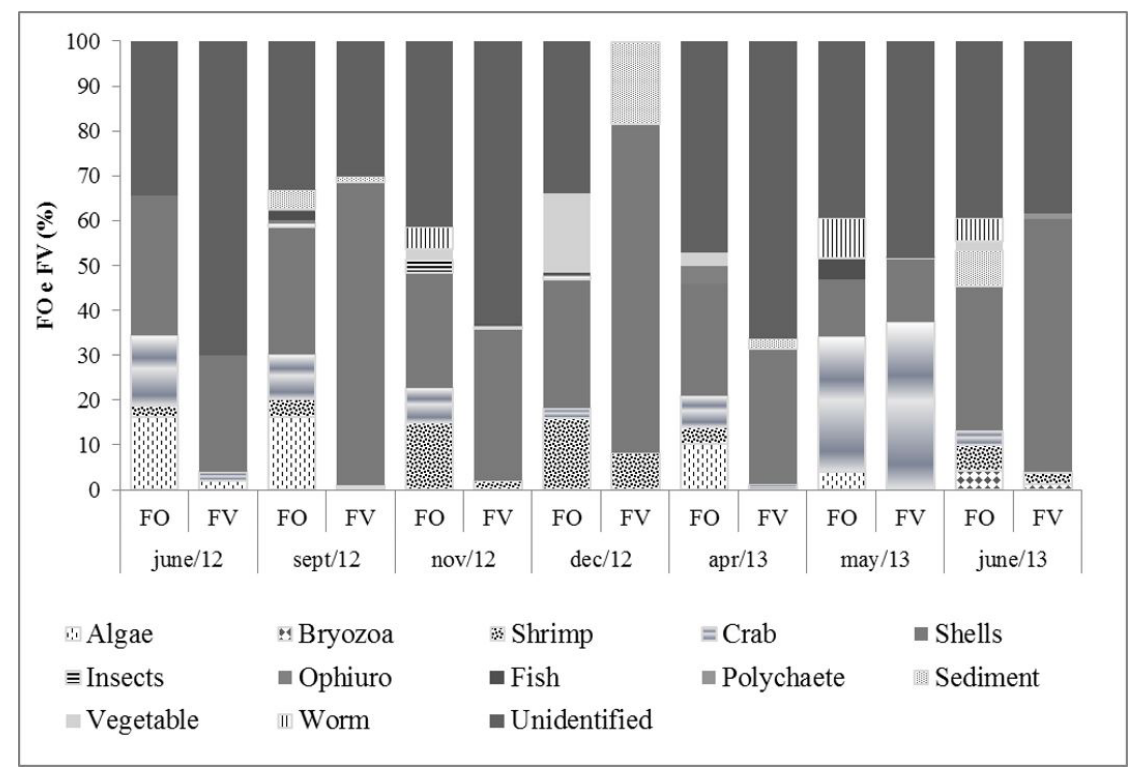

Figure 3. Frequency of occurrence (FO) and Volumetric (FV) of food items present in the stomachs of T. cayennensis specimens caught between June 2012 and June 2013. 
Table 3. Proportion of IAi for each food item analyzed by total length size class (I, II and III)* of T. cayennensis specimens caught between June 2012 and June 2013.

\begin{tabular}{cccc}
\hline \multirow{2}{*}{ Food Item } & \multicolumn{3}{c}{ Size Class (cm)* } \\
\cline { 2 - 4 } & I & II & III \\
\hline Algae & 0.25 & 0.10 & - \\
Bryozoan & 0.25 & - & - \\
Shrimps & - & 0.10 & - \\
Crabs & - & 0.20 & 0.32 \\
Shells & - & 0.30 & 0.44 \\
Insects & 0.02 & - & - \\
Ophiuroids & 0.02 & - & - \\
Fishes & - & - & 0.04 \\
Polychaetes & 0.04 & 0.15 & - \\
Vegetal matter & 0.02 & 0.15 & - \\
Unidentified & 0.40 & - & 0.20 \\
\hline
\end{tabular}

*I: <29.0 cm); II: 29.1 to $37.0 \mathrm{~cm}$; III: $\geq 37.1 \mathrm{~cm}$. polychaetes and vegetal matter, demonstrating a greater diversity of food items (Figure 5).

The size class I, which includes individuals smaller than $29 \mathrm{~cm}$, was characterized by the greater correlation to items of smaller size and greater ease of capture, such as algae, bryozoan and insects.

The NMDS analysis indicated that the relative importance of the different items was not linked to the temporal variation of each month studied. It is observed, at a level of $80 \%$ of similarity, the formation of 2 groups: the first one (G1), consisting mostly of dry months, November and December/2012, besides June/2013 rainy). Group II (GII) was formed mostly by months of the rainy season (June/12 and April/2013), besides September/2012. The high presence of crustaceans and the larger fish record, as food items, observed in the sample of May/2013, caused a dissimilarity in that month, in relation to the others (Figure 6).

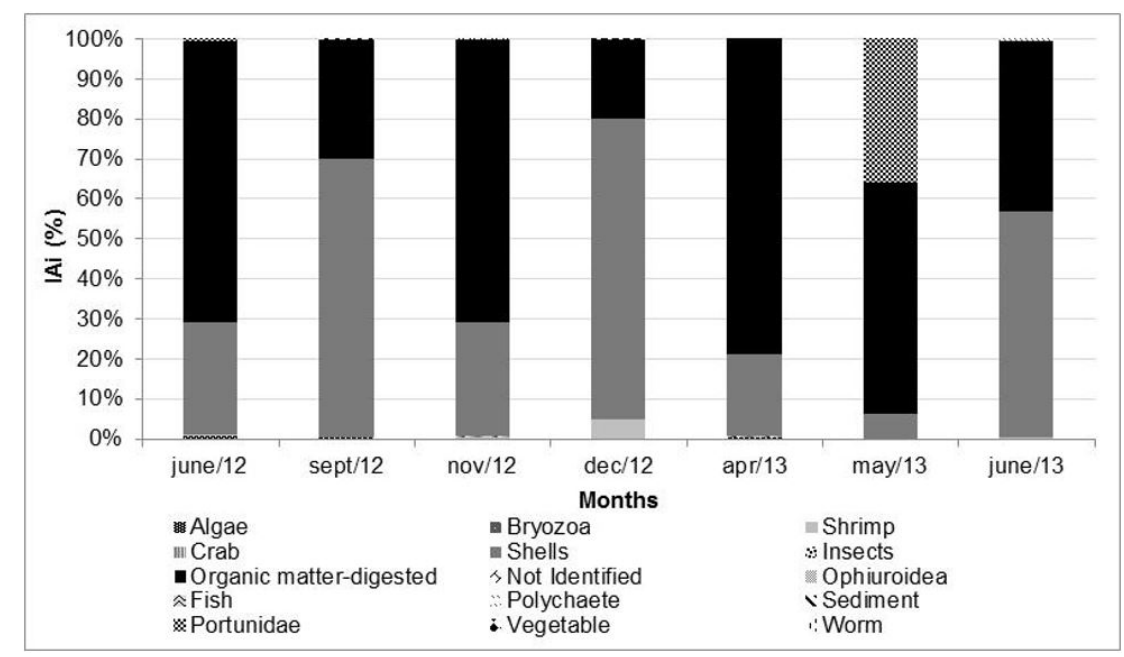

Figure 4. Alimentary importance index for items in digestive tract of T. cayennensis specimens caught between June 2012 and June 2013.

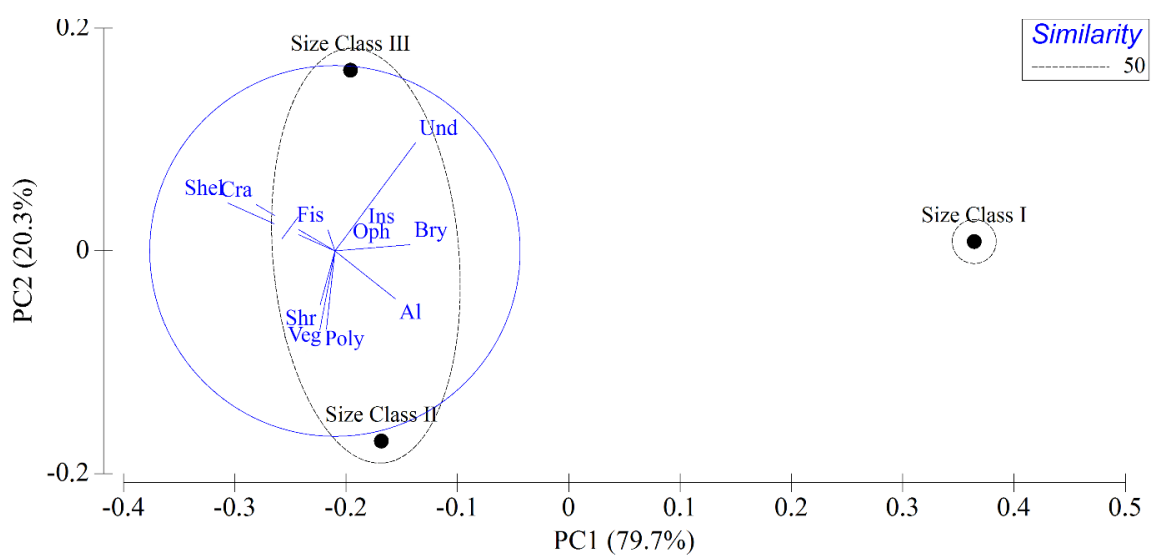

Figure 5. Principal Component Analysis of food items and size class (I, II, III) of T. cayennensis. Al=Algae, Bry=Bryozoan, Shr=Shrimps, Poly=Polychaetes, Veg=Vegetal matter, Cra=Crabs, Shel=Shells, Ins=Insects, Oph=Ophiuroids, Fis=Fish, Und $=$ Unidentified. 


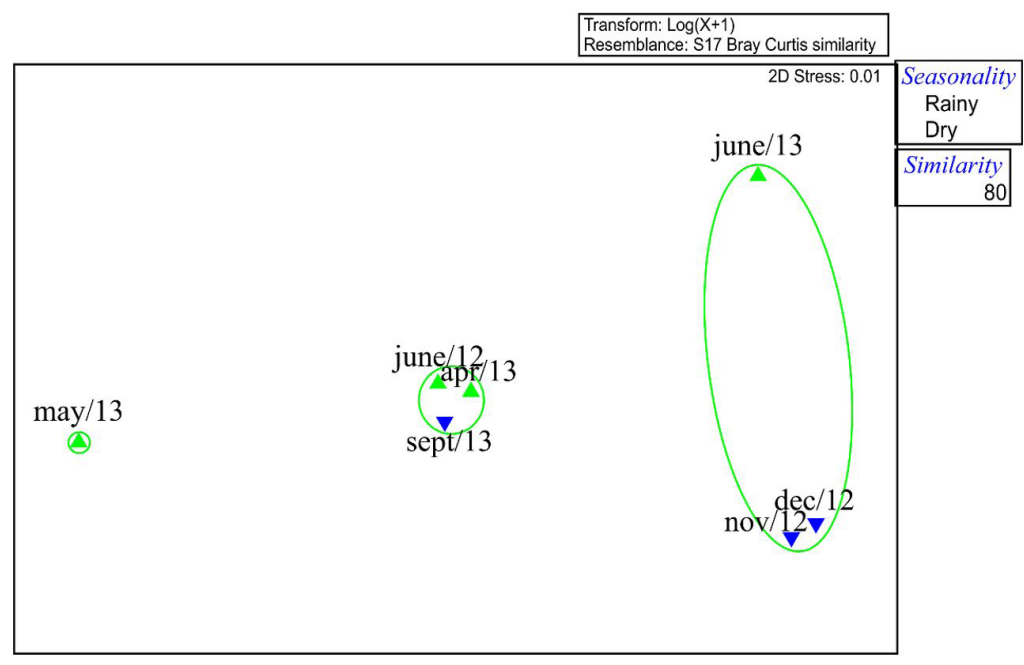

Figure 6. Nonmetric multidimensional scaling (nMDS) ordination of the dietary similarities among months for T. cayennensis caught on western coast of Maranhão.

The SIMPER analysis allowed to distinguish the food items that favored the differentiation between the seasonal periods, being the unidentified (advanced level of digestion), shells, crab and algae, the food that contributed most during the rainy season, allowing a similarity of $72.5 \%$ within the group.

For the dry season group, with $75.3 \%$ similarity, the items that contributed the most were unidentified, shells, shrimp and crab. The dissimilarity between the rainy season and the dry season was $26.9 \%$, with algae, shrimp, vegetable, crab and insect being the major responsible for such differentiation, with greater occurrence, during the dry season for shrimp, insects and vegetable, while algae and crab were more present in the rainy season

\section{Discussion}

Reliable information on feeding relationships is crucial to understanding the ways in which an estuary behaves. The construction of a robust food web for an estuary requires good quantitative data on the dietary compositions of the different species found in this environment. Such data can be in the form of numbers, weights or volumes of the various items in the gut, which are then typically expressed as a percentage of the corresponding totals for those items (D'Souza et al., 2009).

The dietary pattern of $T$. cayennensis is characterized by a considerable high richness of food items, placing this species in the generalist category. In estuaries, the dietary habits of fishes are quite diversified, with representatives from all categories (Caberty et al., 2004). Overall, herbivores are represented by few species; the benthivores are dominant, and both occur in all types of estuaries (Paiva et al., 2008).

Morphological changes during ontogeny are important adaptations, as they enable a species to use new habitats for the consumption of prey items with larger sizes or more energy resources (Fugi et al., 2001; Galarowicz et al.,
2006). Winemiller (1989) postulates that changes in dietary habits in different stages of the life cycle can reduce intra-specific and interspecific overlap in the use of food resources. The juveniles of $T$. cayennensis on western coast of Maranhão revealed trophic ontogeny, including in the diet from algae to other fishes, while adults showed preference for hard-shell organisms.

Studies on feeding habits of other species of pompano have reported a clear pattern of ontogenetic variation in the use of macroinfauna. Santos (2010) observed that proportion of juveniles that used macroinfauna as food resource was related to total length, indicating an increase in the consumption of macroinfauna throughout of growth.

Adult cayenne pompanos demonstrate characteristics of selective consumers, feeding mainly on benthic fauna, while juveniles are considered opportunistic consumers and feed on organisms found in greater abundance and availability.

Female specimens exhibited a greater range of lengths and weights, which confirms the trend of larger values for these characters compared to males among fishes in natural environments.

According to Lemos et al. (2011), individuals of the genus Trachinotus reach first gonadal maturation around $21.14 \mathrm{~cm}$, which indicates the existence of the sustainable exploitation of $T$. cayennensis captured on the west coast of the state of Maranhão, Brazil, considering the higher incidence of individuals captured in the 29.2 to $33.0 \mathrm{~cm}$ class.

With the growth of the species, pharyngeal plates develop, which favors the consumption of organisms with hard shells, such as mollusks, crabs, shrimps and various fish species (Zahorcsak et al., 2000).

The stomach fullness index is considered a good indicator for identifying when fishes find better feeding conditions, providing data on habitat and food availability in the environment and assisting in the clarification of some behavioral aspects (Schoener, 1974; Hahn et al., 1997). 
Intense feeding activity was found for T. cayennensis, as demonstrated by the low number of empty stomachs. The highest frequency of individuals with food was observed from June to December 2012 and may be associated with higher temperature, which causes acceleration of the metabolic rate and increased food intake (Lolis and Andrian, 1996; Marques et al., 1992). One may conjecture, however, that light during the photoperiod may act as an abiotic factor triggering synchronization between the environmental events and feeding activity (Carvalho and Soares, 2006). Moreover, the migration of prey may also occur in such a way as to synchronize it with the light/dark cycle

The success of a species is related to its diet. Although fishes use a broad spectrum of prey items, few predominate in the diet and high consumption of a certain prey item is mainly associated with its abundance in the environment (Palmeira and Monteiro-Neto, 2010). Some fishes exhibit ontogenetic shifts in diet, with changes in the type and size of prey due to the different energy requirements and the potential for resource exploitation (Escalona and Cárdenas, 2004).

In the present study, size Class I (represented by individuals smaller than $29 \mathrm{~cm}$ ) had a diet composed of organisms with smaller dimension and low capacity of locomotion, such as algae, bryozoans and Insects. The larger individuals (Classes II e III) demonstrated a dietary change, with the diet composed predominantly of shells and crabs, besides shrimps, polychaetas, vegetal matter and fishes.

Unidentified organisms were observed in all classes, with greater association with size class I, which is justified by the greater ease of digestion of the foods consumed by the species in its younger phase, making it difficult to identify food items. The changes in ontogenetics for the genus Trachinotus were also observed by several authors (Helmer et al., 1995; Russo et. al., 2007; Palmeira and Monteiro-Neto, 2010).

Studies on the food habits of other populations of the Cayenne pompano report crustaceans and insects, especially ants (Formicidae), as the basis of the diet of juveniles, whereas mollusks, crustaceans and microcrustaceans make up the diet of adults (Batistic et al., 2005; Moreno and Castro, 1995). Crustaceans are the main food item and prey preference of benthic fishes on the southern and northeastern coasts of Brazil (Zahorcsak et al., 2000).

The presence of crustaceans (shrimps and crabs) and mollusks (bivalves) throughout all months sampled in the present study is in agreement with descriptions by Menezes and Figueiredo (1980) and Cervigon (1996), who describe the Cayenne pompano as a usual predator, feeding primarily on benthic invertebrates, crustaceans, mollusks and fishes.

The greater variety of food items in the stomachs of T. cayennensis from the western coast of Maranhão may be attributed to the occurrence of these resources in areas of low energy (bays, creeks and estuaries). Most studies about other genus Trachinotus have been conducted in areas with greater wave exposure, in which the variability of environmental conditions imposes a community with low diversity, low richness and high numerical dominance by a few species (Niang et al., 2010; Brown and Mclachlan, 1990).

Bottom-dwelling organisms, such as bivalves, crabs and shrimps, were frequent and significant in the diet of the Cayenne pompano on the western coast of Maranhão. Other authors report similar findings along the Brazilian coast, such as Cassino Beach in the state of Rio Grande do Sul (Monteiro-Neto and Cunha, 1990), Camburi Beach in the state of Espírito Santo (Helmer et al., 1995) and sandy beaches in the state of Rio de Janeiro (Niang et al., 2010).

According to some authors, morphology explains the importance of mollusks and crustaceans in the diet of T. cayennensis. Studying the genus Trachinotus, Francillon-Vieillot et al. (1994) noted that the development of the pharyngeal teeth is complete when the individual reaches $5.0 \mathrm{~cm}$ in size. This allows the grinding of shells and may determine the inclusion of these items in the diet. Ecomorphological studies are an important tool for explaining diet partitioning among species of the genus. Morphological changes during ontogenic development are important adaptations that enable species to use new habitats for consuming larger prey items or those of greater energy resources (Fugi et al., 2001).

Lençóis Bay maintains a population of $T$. cayennensis that uses this area for feeding and growth, with a diet predominated by benthic invertebrates among smaller individuals as well as shells and crustaceans among adults. The variety of items in the diet of T. cayennensis indicates considerable trophic plasticity and opportunistic behavior. Seasonal variations influenced the trophic pattern of the species, with the highest feeding activity in the dry period. The considerable availability of resources in estuarine habitats of the western coast of Maranhão constitutes another factor that exerts an influence on the feeding behavior of this species. The present findings on the feeding activity pattern found in this study may contribute to fishery strategies for the management of this potentially exploitable economic resource.

\section{Acknowledgements}

We acknowledge support from FAPEMA (Fundação de Amparo à Pesquisa e ao Desenvolvimento Científico e Tecnológico do Maranhão). The authors would like to thank the Laboratory of Ichthiology and Fishery Resources of the Departament of Oceanography and Limnology of Federal University of Maranhão for logistic supports. In addition, we wish to thank two anonymous reviewers for constructive comments on the manuscript.

\section{References}

BATISTIC, M., TUTMAN, P., BOJANIC, D., SKARAMUCA, B., KO[ZBREVE]UL, V., GLAVIC, N. and BARTULOVIC, V., 2005. Diet and diel feeding activity of juvenile pompano ( Trachinotus ovatus ) (Teleostei: Carangidae) from the southern Adriatic, Croatia. Journal of the Marine Biological Association 
of the United Kingdom, vol. 85, no. 6, pp. 1533. http://dx.doi. org/10.1017/S0025315405012749.

BELLINGER, J.W. and AVAULT JUNIOR, J.W., 2011. Food habits of Juvenile Pompano, Trachinotus carolinus, in Louisiana. Transactions of the American Fisheries Society, vol. 100, no. 3, pp. 486-494. http://dx.doi.org/10.1577/1548-8659(1971)100<486:FH OJPT $>2.0 . \mathrm{CO} ; 2$

BROWN, A.C. and MCLACHLAN, A., 1990. Ecology of sandy shores. Amsterdam: Elsevier. 328 p.

CABERTY, S., BOUCHEREAU, J. and CHAVES, P.T., 2004. Organisation et fonctionnement trophiques de l'assemblage ichtyque d'um écosystème lagunaire à mangrove antillais au moyen de l'indice trophique de contribution. Cahiers de Biologie Marine, vol. 45, no. 1, pp. 243-254.

CAMPOS, D.M.A.R., SILVA, A.F., SALES, N.S., OLIVEIRA, R.E.M.C.C. and PESSANHA, A.L.M., 2015. Trophic relationships among fish assemblages in a mudflat within Brazilian marine protected area. Brazilian Journal of Oceanography, vol. 63, no. 1, pp. 135-146. http://dx.doi.org/10.1590/S1679-87592015091306302.

CAPITOLI, R.R., 1992. Métodos para estimar volumes do conteúdo alimentar de peixes e macroinvertebrados. Atlântica, vol. 14 , no. 1 , pp. 117-120.

CARVALHO, M.R. and SOARES, L.S.H., 2006. Diel feeding pattern and diet of rough scad Trachurus lathami Nichols, 1920 (Carangidae) from the Southwestern Atlantic. Neotropical Ichthyology, vol. 4, no. 4, pp. 419-426. http://dx.doi.org/10.1590/ S1679-62252006000400005.

CERVIGON, F.M., 1996. Los peces marinos de Venezuela. Caracas: Fundación La Salle de Ciencias Naturales. 438 p.

CLARKE, K.R. and GORLEY, R.N., 2001. Software PRIMER. Plymouth: PRIMER-E.

CLARKE, K.R. and WARWICK, R.M., 1994. Change in marine communities: an approach to statistical analysis and interpretation. Plymouth: Natural Environment Research Council. 144 p.

D'SOUZA, F., STORER, T. and ROBB, M., 2009. Fish diets and food webs in the Swan-Canning estuary. River Science, vol. 28 , no. 1, pp. 1-12.

EL-ROBRINI, M., SILVA, M.A.M.A., SOUZA FILHO, P.W.M., EL-ROBRINI, M.H.S., SILVA JÚNIOR, O.G. and FRANÇA, C.F., 2006. Pará. In: D. MUEHE, org. Erosão e progradação do litoral brasileiro. Brasília: Ministério do Meio Ambiente, pp. 41-86.

ESCALONA, V.H.C. and CÁRDENAS, L.A.A., 2004. General characteristics of the diet of Trachinotus paitensis (Teleostei: Carangidae) from San Ignacio Lagoon, Baja California Sur, Mexico. Revista de Biología Tropical, vol. 52, no. 1, pp. 139-141. http://dx.doi.org/10.15517/rbt.v52i1.14762. PMid:17357410.

FATEMA, K., OMAR, W.M.W. and ISA, M.M., 2013. Identification of food and feeding habits of Mullet Fish, Liza Subviridis (Valenciennes, 1836), Valamugil Buchanani (Bleeker, 1853) from Merbok Estuar. Journal of Life Sciences and Technologies, pp. 47-50. http://dx.doi.org/10.12720/jolst.1.1.47-50.

FIGUEIREDO, J.L. and MENEZES, N.A., 2000. Manual de peixes marinhos do sudeste do Brasil. São Paulo: Museu de Zoologia da USP. 116 p. VI Teleostei, 5.

FONTELLES-FILHO, A.A., 2011. Oceanografia, biologia e dinâmica populacional de recursos pesqueiros. Fortaleza: Expressão Gráfica e Editora. 464 p.
FRANCILLON-VIEILLOT, H., TRÉBAOL, L., MEUNIER, F.J. and SLEMBROUCK, J., 1994. Histological study of odontogenesis in the pharyngeal jaws of Trachinotus teraia (Cuvier et Valenciennes, 1832) (Osteichthyes, Teleostei, Carangidae). Journal of Morphology, vol. 220, no. 1, pp. 11-24. http://dx.doi. org/10.1002/jmor.1052200103. PMid:29865386.

FUGI, R., AGOSTINHO, A.A. and HAHN, N.S., 2001. Trophic morphology of five benthic-feeding fish species of a tropical floodplain. Brazilian Journal of Biology $=$ Revista Brasleira de Biologia, vol. 61, no. 1, pp. 27-33. http://dx.doi.org/10.1590/ S0034-71082001000100005. PMid:11340459.

GALAROWICZ, T.J., ADAMS, J.A. and WAHL, D.H., 2006. The influence of prey availability on ontogenetic diet shifts of a juvenile piscivore. Su Ürünleri Dergisi, vol. 63, no. 1, pp. 1722-1733.

GÓMES, A., 2002. Selección de peces marinos para cultivos intensivos em el nororiente de Venezuela. Boletin de Investigaciones Marinas y Costeras, vol. 31, no. 1, pp. 53-63.

HAHN, N.S., ADRIAN, I.F., FUGI, R. and ALMEIDA, V.L.L., 1997. Ecologia trófica. In: A.E.A.M. VAZZOLER, A.A. AGOSTINHO and N.S. HAHN, eds. A planície de inundação do Alto Rio Paraná: aspectos físicos, biológicos e socioeconômicos. Maringá: EDUEM, pp. 209-228.

HELMER, J.L., TEIXEIRA, R.L. and MONTEIRO-NETO, C., 1995. Food habits of young Trachinotus (Pisces, Carangidae) in the inner surf zone of a sandy beach in southeast Brazil. Atlantica, vol. 17, no. 1, pp. 95-107.

HYNES, H.B.N., 1950. The food of fresh-water sticklebacks (Gasterosteus aculeatus and Pygosteus pungitius) with a review of methods used in studies of the food of fishes. Journal of Animal Ecology, vol. 19, no. 1, pp. 36-58. http://dx.doi.org/10.2307/1570.

HYSLOP, E.J., 1980. Stomach contents analysis a review of methods and their applications. Journal of Fish Biology, vol. 17, no. 1, pp. 411-429. http://dx.doi.org/10.1111/j.1095-8649.1980. tb02775.x.

KAWAKAMI, E. and VAZZOLER, G., 1980. Método gráfico e estimativa do índice alimentar aplicado no estudo da alimentação de peixes. Boletim do Instituto Oceanográfico, vol. 29, no. 2, pp. 205-207. http://dx.doi.org/10.1590/S0373-55241980000200043.

LEFÈVRE, N., DIAS, F.J.S., TORRES JUNIOR, A.R., NORIEGA, C., ARAUJO, M., CASTRO, A.C.L., ROCHA, C., JIANG, S. and IBÁNHEZ, J.S.P., 2017. A source of CO 2 to the atmosphere throughout the year in the Maranhense continental shelf $\left(2^{\circ} 30^{\prime} \mathrm{S}\right.$, Brazil). Continental Shelf Research, vol. 141, no. 1, pp. 38-50. http://dx.doi.org/10.1016/j.csr.2017.05.004.

LEMOS, V.M., VARELA JUNIOR, A.S., VELASCO, G. and VIEIRA, J.P., 2011. The reproductive biology of the plata pompano, Trachinotus marginatus (Teleostei: Carangidae), in southern Brazil. Zoologia, vol. 28, no. 5, pp. 603-609. http:// dx.doi.org/10.1590/S1984-46702011000500008.

LIMA, D.O. and BEHR, E.R., 2010. Feeding ecology of Pachyurus bonariensis Steindachner, 1879 (Sciaenidae: Perciformes) in the Ibicuí River, Southern Brazil: ontogenetic, seasonal and spatial variations. Brazilian Journal of Biology $=$ Revista Brasileira de Biologia, vol. 70, no. 3, pp. 503-509. http://dx.doi.org/10.1590/ S1519-69842010000300006. PMid:20730336.

LOLIS, A.A. and ANDRIAN, I.F., 1996. Alimentação de Pimelodus maculatus Lacépède, 1803 (Siluriformes, Pimelodidae) na planície 
de inundação do Alto Rio Paraná. Boletim do Instituto da Pesca, vol. 23, no. 1, pp. 187-202.

LOWE-MCCONNELL, R.H., 1999. Estudos ecológicos de comunidades de peixes tropicais. São Paulo: Edusp. 535 p.

LUZ, K.D.G., ABUJANRA, F., AGOSTINHO, A.A. and GOMES, L.C., 2001. Caracterização trófica da ictiofauna de três lagoas da planície aluvial do alto rio Paraná, Brasil. Acta Scientiarum, vol. 23 , no. 2, pp. 401.

MARQUES, E.E., AGOSTINHO, A.A., SAMPAIO, A.A. and AGOSTINHO, C.S., 1992. Alimentação, evacuação gástrica e cronologia da digestão de jovens de pintado Pseudoplatystoma corruscans (Siluriformes, Pimelodidae) e suas relações com a temperatura ambiente. Revista Unimar, vol. 14, no. 1, pp. 207-221.

MCMASTER, M.F., 2014 [viewed 13 July 2017]. FAO Cultured species sheet Florida pompano (Trachinotus carolinus) [online]. Florida: FAO. 23 p. Available from: http://www.mariculturetechnology. com/FAOCULTUREDSPECIESSHEET.pdf

MENEZES, N.A. and FIGUEIREDO, J.L., 1980. Manual de peixes marinhos do sudeste do Brasil. São Paulo: Editora Museu de Zoologia da USP. 63 p.

MONTEIRO-NETO, C. and CUNHA, L.P.R., 1990. Seasonal and ontogenetic variation in food habits of juvenile Trachinotus marginatus Cuvier 1832 (Teleostei Carangidae) in the surf zone of Cassino Beach, RS, Brazil. Revista Atlântica, vol. 12, no. 1, pp. $45-54$.

MORENO, T. and CASTRO, J.J., 1995. Community structure of the juvenile of coastal pelagic fish species in the Canary Islands waters. Scientia Marina, vol. 59, no. 1, pp. 405-413.

NIANG, T.M.S., PESSANHA, A.L.M. and ARAUJO, F.G., 2010. Dieta de juvenis de Trachinotus carolinus (Actinopterygii, Carangidae) em praias arenosas na costa do Rio de Janeiro. Iheringia. Série Zoologia, vol. 100, no. 1, pp. 35-42. http://dx.doi. org/10.1590/S0073-47212010000100005.

OLIVEIRA, M.R., COSTA, E.F.S., ARAÚJO, A.S., PESSOA, E.K.R., CARVALHO, M.M., CAVALCANTE, L.F.M. and CHELLAPPA, S., 2012. Sex ratio and length-weight relationship for five marine fish species from Brazil. Journal of Marine Biology \& Oceanography, vol. 1, no. 2, pp. 3. http://dx.doi. org/10.4172/2324-8661.1000103.

PAIVA, A.C.G., CHAVES, P.T. and ARAÚJO, M.E., 2008. Estrutura e organização trófica da ictiofauna de águas rasas em um estuário tropical. Revista Brasileira de Zoologia, vol. 25, no. 4, pp. 647-661. http://dx.doi.org/10.1590/S0101-81752008000400010.
PALMEIRA, L.P. and MONTEIRO-NETO, C., 2010. Ecomorphology and food habits of teleost fishes Trachinotus carolinus (teleostei: carangidae) and Menticirrhus littoralis (teleostei: sciaenidae), inhabiting the surf zone off Niterói, Rio de Janeiro, Brazil. Brazilian Journal of Oceanography, vol. 58, no. 4, pp. 1-9. Special Issue. http://dx.doi.org/10.1590/S167987592010000800002

REBELO-MOCHEL, F. and PONZONI, F.J., 2007. Spectral characterization of mangrove leaves in the Brazilian Amazonian Coast: Turiaçu Bay, Maranhão State. Anais da Academia Brasileira de Ciências, vol. 79, no. 4, pp. 683-692. http://dx.doi.org/10.1590/ S0001-37652007000400009. PMid:18066436.

RESCHKE, G.A., ELOI, C.M.A. and SILVA, R.M., 2011. Caracterização climática da Amazônia maranhense. In: M.B. MARTINS and T.G. OLIVEIRA, eds. Amazônia maranhense: diversidade e conservação. Belém: MPEG, pp. 47-67.

RUSSO, T., COSTA, C. and CATAUdELlA, S., 2007. Correspondence between shape and feeding habit changes throughout ontogeny of gilthead sea bream Sparus aurata L., 1758. Journal of Fish Biology, vol. 71, no. 3, pp. 629-656. http:// dx.doi.org/10.1111/j.1095-8649.2007.01528.x.

SANTOS, J.N.S., 2010. Relação entre morfologia e dieta e uso da macroinfauna por pampos Trachinotus carolinus e Trachinotus goodei (Actinopterygii, Carangidae) em duas praias arenosas do sudeste do Brasil. Rio de Janeiro: Universidade Federal Rural do Rio de Janeiro, 89 p. Tese de Doutorado em Biologia Animal.

SCHOENER, T.W., 1974. Resources partitioning in ecological communities. Science, vol. 185, no. 4145, pp. 27-39. http://dx.doi. org/10.1126/science.185.4145.27. PMid:17779277.

VALENTIN, J.L. 2012. Ecologia numérica: uma introdução à análise multivariada de dados ecológicos. Rio de Janeiro: Interciência. 168 p.

WINEMILLER, K.O., 1989. Patterns of variation in life story among South American fishes in seasonal environments. Oecologia, vol. 81, no. 2, pp. 225-241. http://dx.doi.org/10.1007/ BF00379810. PMid:28312542.

WOOTTON, R.J. 1992. Fish ecology. New York: Chapman and Hall. 212 p. http://dx.doi.org/10.1007/978-94-011-3832-1.

ZAHORCSAK, P., SILVANO, R.A.M. and SAZIMA, I., 2000. Feeding biology of a guild of benthivorous fishes in a sandy shore on South-Eastern Brazilian Coast. Revista Brasileira de Biologia, vol. 60, no. 3, pp. 511-518. http://dx.doi.org/10.1590/ S0034-71082000000300016. PMid:11188877.

ZALE, A.V., PARRISH, H.D.L. and SUTTON, T.M. 2012. Fisheries techniques. Maryland: American Fisheries Society. 1069 p. 